\title{
Penerapan E-Tilang dalam Penyelesaian Tindak Pidana Pelanggaran Lalu Lintas
}

\author{
Uni Sabadina \\ Fakultas Hukum, Universitas Muhammadiyah Yogyakarta \\ Email : Unisabadina97@gmail.com
}

\author{
Info Artikel \\ Kata Kunci : \\ Elektronik Tilang, \\ Lalu Lintas, \\ Penegakan Hukum \\ Perjalanan Artikel : \\ Diterima : 25 Januari 2020 \\ Direview : 01 Februari 2020 \\ Ditinjau : 20 Maret 2020 \\ Dipublikasikan : Maret 2020
}

DOI: 10.18196/ijclc.v1i1.9157

\section{Pendahuluan}

Yogyakarta dikenal sebagai mini Indonesia dimana banyak pelajar yang datang dari berbagai daerah termasuk pelajar dari Yogyakarta itu sendiri untuk menuntut ilmu di Yogyakarta. Hal tersebut yang menjadikan banyaknya pendatang di daerah Yogyakarta yang merantau di daerah Yogyakarta, dengan demikian bertambahlah juga jumlah kendaraan yang berada di daerah Yogyakarta itu sendiri, hasil survei dari Dinas Perhubungan Kota Yogyakarta peningkatan kendaraan tiap tahunnya mencapai 140 ribu hingga 150 ribu. Oleh karna itu transportasi baik dengan sepeda motor maupun mobil sangatlah penting untuk menempuh atau mencapai tempat-tempat belajar baik ditingkat SMA maupun ditingkat Perguruan Tinggi. Sejalan dengan itu berbagai kegiatan aktivitas masyarakat kota Yogyakarta didalamnya, seperti bekerja dan mengantar serta menjemput anak ke sekolah bagi orang tua. Hal ini menjadikan transportasi sangatlah diperlukan dalam memenuhi kebutuhan sehari-hari.

Transportasi yang semakin banyak di dalam suatu kota guna membantu aktivitas sehari-hari masyarakat di dalamnya. Pelanggaran lalu lintas pun pastinya tidak dapat terelakkan. Seperti melanggar rambu-rambu lalu lintas, melewati marka jalan, menerobos lampu lalu lintas, tidak membawa kelengkapan berkendara seperti SIM dan STNK dan lain-lain, bahkan terkadang

\begin{abstract}
Abstrak
kendaraan tiap tahunnya mencapai 140 ribu hingga 150 ribu.Transportasi yang semakin banyak, pelanggaran lalu lintas pastinya tidak dapat terelakkan. Proses tilang yang selama ini telah dilakukan secara konvensional masih kurang dalam
pemberlakuannya, Pihak Kepolisian melakukan inovasi baru yaitu E-Tilang. Melihat hasil dari E-Tilang hasilnya masih belum maksimal. Dengan mengacu pada rumusan masalah yang ada mengenai pelaksanaan sistem E-Tilang dalam menyelesaikan
perkara tindak pidana pelanggaran lalu lintas dan penerapan sanksi melalui sistem E-Tilang. Penelitian ini penelitian hukum kacamata untuk melihat bekerjanya aspek hukum yang saat ini berlaku dengan keadaan nyata di lapangan, apakah terjadi digunakan penelitian ini adalah data sekunder, dimana data yang adalah E-Tilang di wilayah hukum Polresta Yogyakarta dilakuk ini dengan Elektronik untuk sistem pembayarannya dendanya pelanggar membayar denda melalui Bank tanpa harus datang ke Pengadilan, terkait sanksi akan diberikan denda sesuai dengan pelanggaran yang telah dilakukan oleh pelanggar, dalam proses penegakan perkara tindak pidana pelanggaran lalu lintas di yang berlaku.
\end{abstract}


mengakibatkan kecelakaan lalu lintas bagi pengguna jalan itu sendiri ataupun mengakibatkan pengguna jalan lain kecelakaan hingga terluka ataupun sampai meninggal dunia. Pelanggaranpelanggaran ini pun terjadi pada jam-jam sibuk seperti pagi hari ketika akan berangkat sekolah, kuliah, dan bekerja. Lalu sore hari ketika pulang sekolah, kuliah, dan bekerja.

Proses tilang yang selama ini telah dilakukan secara konvensional diharapkan mampu untuk mengurangi tingkat pelanggaran lalu lintas, dimana cara kerja sistem tilang konvensional tersebut masih menggunakan sistem kertas dalam salah satu pemberlakuannya. Sistem tilang manual yang menggunakan blangko atau surat tilang. ${ }^{1}$. Pada saat pengguna lalu lintas terbukti melakukan kesalahan atau pelanggaran maka petugas kepolisian akan melakukan beberapa tindakan, mekanisme tilang untuk formulir berwarna merah adalah sebagai berikut: ${ }^{2}$

1. Polri menindak menggunakan formulir berwarna merah

2. Penetapan hari sidang harus memperhatikan ketetapan dari pengadilan

3. Jelaskan kapan dan dimana pelanggar harus menghadiri sidang

4. Bila pelanggar tidak hadir, Polri wajib 2 kali memanggil dan ke3 kalinya melakukan penangkapan.

5. Pengembalian barang bukti menunggu selesainya sidang dansetelah pelanggar membayar denda ke Panitera.

Namun tilang konvensional ini dirasa masih kurang dalam pemberlakuannya, sehingga membuat Pihak Kepolisian melakukan inovasi terkait sistem tilang yang baru. Perkembangan teknologi telah membawa dampak dalam kehidupan yang sangat pesat pada masyarakat. Pada masa kini sebagian masyarakat semakin merasakan perkembangan teknologi, salah satunya adalah dengan semakin berkembangnya bisnis pelayanan informasi, seperti stasiun televisi, surat kabar, radio, internet dan lain sebagainya. Oleh sebab itu E-Tilang ini dirasa cocok dengan perkembangan zaman pada era modern seperti saat ini. Dimana segala sesuatu yang berhubungan dengan kegiatan masyarakat di bantu dengan sistem berbasis elektronik.

Hal semacam inilah yang menjadikan pihak kepolisian memberlakukan sistem E-Tilang yang diharapkan mampu mengurangi tingkat pelanggaran-pelanggaran lalu lintas pada masyarakat dan di harapkan mampu menghindarkan dari pungutan liar yang belakangan ini sering terjadi. E-Tilang adalah sebuah layanan berbasis elektronik melalui aplikasi mobile yang berfungsi untuk melakukan transaksi pembayaran titipan denda tilang BRI secara online, dimana masyarakat (pelanggar lalu lintas) tidak harus datang ke Kejaksaan Negeri untuk melakukan pembayaran titipan denda tilang secara manual sehingga memudahkan dan mempercepat masyarakat dalam penyelesaian perkara pelanggaran lalu lintas. ${ }^{3}$ Terlebih bagi yang tidak bertempat tinggal di wilayah kota Yogyakarta, jadi ketika seseorang yang datang ke Kota Yogyakarta untuk sekedar bermain dan berwisata, tetapi terkena tilang. Sehingga E-Tilang memudahkan masyarakat (pelanggar lalu lintas) tanpa harus mengikuti sidang tilang di Pengadilan Negeri Yogyakarta.

Salah satu wilayah yang sudah menerapkan sistem E-Tilang di wilayah hukum Polresta Yogyakarta adalah di perempatan Pingit. Di samping itu E-Tilang merupakan salah satu alternatif dalam proses penilangan yang sekarang sedang di kembangkan oleh Pihak Kepolisian Lalu Lintas, menggunakan cara digitalisasi dalam proses tilang, karena dengan memanfaatkan teknologi diharapkan E-Tilang mampu mempermudah proses tilang yang ada. E-Tilang secara umum adalah ETilang yang dimana cara kerja E-Tilang itu sendiri untuk mempermudah proses penilangan yang dilakukan oleh pengendara. Seperti untuk mempermudah akses pengendara yang melanggar dalam pembayaran denda sesuai dengan pelanggaran yang dilakukan, dan di harapkan mampu mengurangi bahkan meniadakan tindakan pungli yang dilakukan oleh oknum-oknum Polisi yang tidak bertanggung jawab dan tidak mematuhi etika sebagai penegak hukum.

1 Setiyanto, Gunarto, Sri Endah Wahyuningsih, Efektivitas Penerapan Sanksi Denda E-Tilang, Jurnal Hukum Khaira Ummah, 2017, Volume. 12 Nomor. 4, hlm. 742- 766.

2 http://indrayanti prastica-fisip15.web.unair.ac.id. Diakses pada tanggal 8 Mei 2019, pukul 23.12 WIB.

3 Abdul Azis, Dias Ayu Budi Utami dan Albertus Novian BT, Prototype Data Warehouse Aplikasi eM-Tilang, Jurnal Sistem Informasi \& Manajemen Basis Data (SIMADA), 2018, Vol. 1 No. 2, hlm. 151 
Tetapi melihat hasil dari penerapan E-Tilang di wilayah hukum Polresta Yogyakarta ini, hasilnya masih belum maksimal. Dalam situasi saat ini E-Tilang belum benar-benar terlaksana secara menyeluruh dan menjadi suatu kebiasaan, maksudnya disini adalah masih banyak masyarakat yang belum paham terkait dengan E-Tilang itu sendiri, dan disisi lain masyarakat banyak yang masih enggan menyelesaikan masalah penilangan, yang dimana masyarakat lebih cenderung menyelesaikan masalah di tempat tilang itu dengan mengupah (sogok) polisi yang sedang bertugas untuk bebas dari penilangan itu sendiri.

Dengan kata lain Pemerintah terkait E-Tilang ini belum maksimal terlaksana dalam mengeksistensikan E-Tilang itu sendiri. Disamping itu dalam menerapkan E-Tilang tidak membutuhkan peraturan-peraturan yang menunjang agar terlaksana dengan baik dan juga yang terpenting hal ini menjadi tugas penting dari Kepolisian adalah bagaimana mensosialisasikan masyarakat terhadap peraturan tersebut. Agar masyarakat juga dapat menerapkan aturan yang telah dikeluarkan demi terciptanya lalu lintas yang teratur dan tertib.

\section{Rumusan Masalah}

Dari latar belakang masalah di atas, maka penulis dapat membatasi masalah sebagai berikut:

Bagaimana E-Tilang diterapkan dalam penyelesaian tindak pidana lalu lintas di wilayah hukum Polresta Yogyakarta?

\section{Metode Penelitian}

Peranan metode penelitian dalam suatu penelitian antara lain untuk menambah kemampuan ilmuan mengadakan atau melakukan penelitian secara lebih baik atau lebih lengkap. Metodologi merupakan unsur yang mutlak harus ada didalam penelitian dan pengembangan ilmu pengetahuan. ${ }^{4}$ Dalam hal ini, penulis akan menggunakan penelitian normatif, yang mana penelitian ini di dasarkan pada analisis atas suatu fakta yang berada di lapangan terhadap peraturan-peraturan yang mengaturnya. Dalam buku Dualisme Penelitian Hukum karya Mukti Fajar dan Yulianto Achmad, memuat pendapat Soerjono Soekanto bahwa :

"Penelitian hukum itu berdasarkan tujuannya terdiri atas pertama: Penelitian hukum Normatif, yang mencakup penelitian terhadap asas-asas hukum, penelitian terhadap sistematika hukum, penelitian terhadap taraf sinkronisasi hukum, penelitian sejarah hukum, dan penelitian perbandingan hukum. Kedua: Penelitian hukum sosiologis atau empiris yang mencakup, penelitian terhadap identifikasi hukum (tidak tertulis) dan penelitian terhadap efektivitas hukum". ${ }^{5}$

Menggunakan bahan hukum primer yang berupa Undang-Undang Nomor 22 Tahun 2009 tentang Lalu Lintas Angkutan Jalan, bahan hukum sekunder mengenai kajian teoritis yang berupa studi pustaka, pendapat hukum, ajaran (doktrin), hasil penelitian, jurnal ilmiah, dan literatur yang terkait.

Narasumber dalam penelitian ini adalah Bapak Iptu Suwardi yang menjabat sebagai KAUR BIN OPS Lantas Polresta Yogyakrta dan Bapak Asung Waluyo, S.H. M.M. selaku Kepala Seksi Pengendalian Operasional Dinas Perhubungan Kota Yogyakarta.

\section{Hasil Penelitian dan Analisis}

Tilang yang dilakukan di wilayah hukum Polresta Yogyakarta, dilakukan oleh petugas Kepolisian Lalu Lintas, yang melakukan tangkap tangan terhadap pelanggar lalu lintas. Pelanggaran yang dilakukan pun banyak macamnya seperti melanggar lampu APIL (Alat Pemberi Isyarat Lalu Lintas), tidak membawa kelengkapan surat-surat berkendara, tidak menggenakan helm dan lain sebagainya.

4 Soerjono Soekanto, Pengantar Penelitian Hukum, Jakarta, UI-Press, 2010, hlm. 5.

5 Mukti fajar ND dan Yulianto Achmad, Dualisme Penelitian Hukum Normatif dan Empiris, Yogyakarta Pustaka Pelajar, 2017, hlm. 153. 
Bagan 1. Mekanisme Perkara Tilang Polri

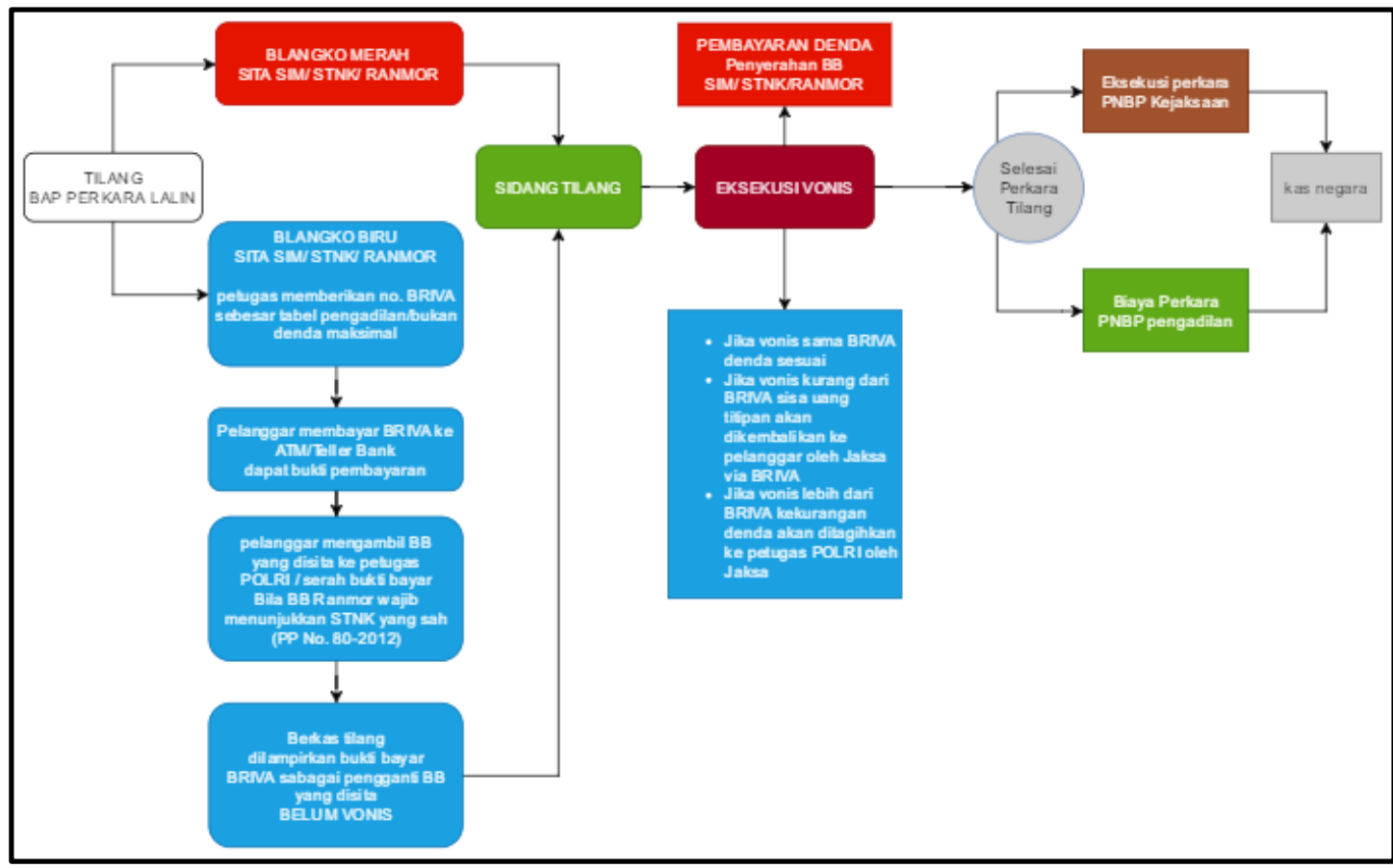

Sumber : Diolah dari data di Polresta Yogyakarta

Berdasarkan dari hasil wawancara yang telah dilakukan oleh peneliti dengan Bapak IPTU Suwardi selaku KAUR BIN OPS Lantas di Polresta Yogyakarta pada tanggal 14 Maret 2019, menurut narasumber proses penegakan hukum E-Tilang di wilayah hukum Polresta Yogyakarta sudah dilakukan oleh petugas lalu lintas dan berpedoman pada Undang-Undang Nomor 29 Tahun 2009 tentang Lalu Lintas dan Angkutan Jalan.

Polisi yang sudah melakukan tindakan tilang kepada pelanggar lalu lintas, akan menawarkan kepada pelanggar dua macam surat. Surat pertama berwarna merah yaitu adalah sistem tilang manual sebagaimana dijelaskan pada bagan 1 .

\section{Gambar 1. Surat tilang manual}

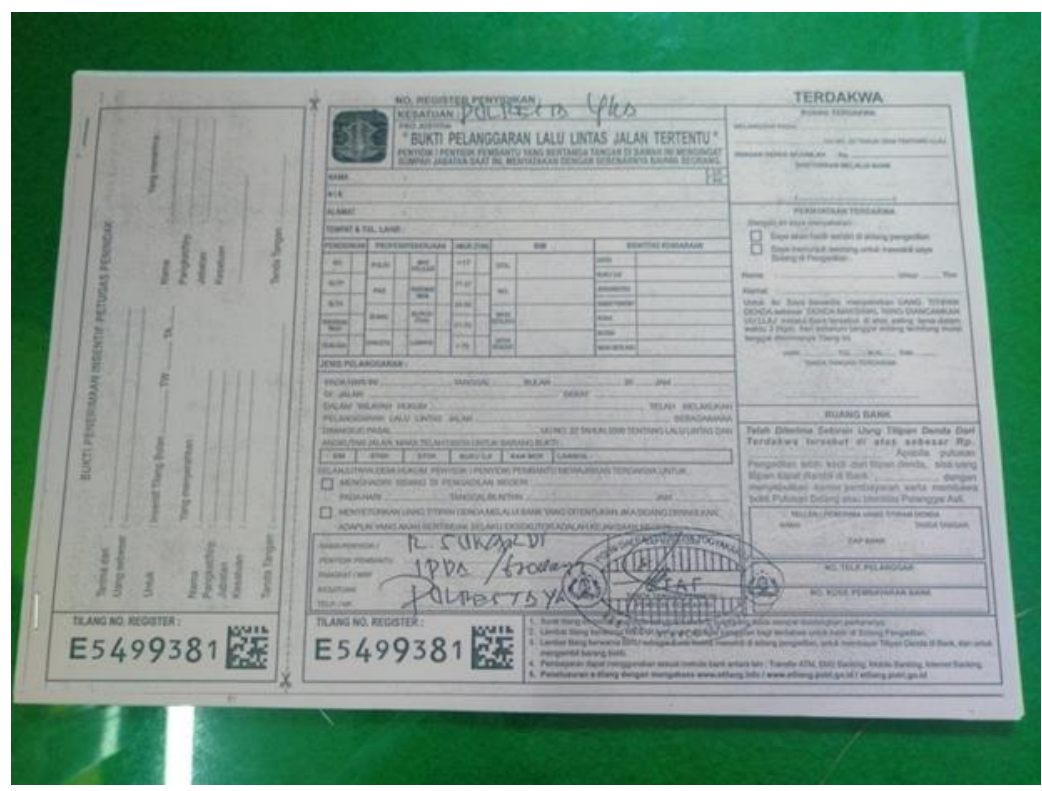

Sumber : Diolah dari data di Polresta Yogyakarta 
Dimana nanti si pelanggar akan diberikan surat tilang berwarna merah seperti pada gambar 1 dan akan dibawa ke Pengadilan untuk persidangan. Persidangan yang dilakukan disini adalah dengan cara cepat, ringan, biaya murah, dan tidak butuh pembuktian. Setelah dilakukannya persidangan, surat tersebut akan dipergunakan untuk membayar denda serta untuk mengambil barang bukti yang disita seperti SIM atau STNK di Kejaksaan.

Berdasarkan dari hasil wawancara yang telah dilakukan oleh peneliti dengan Bapak Asung Waluyo, S.H. M.M. selaku Kepala Seksi Pengendalian Operasional Dinas Perhubungan Kota Yogyakarta pada tanggal 26 Maret 2019, menurut narasumber proses penegakan hukum E-Tilang di wilayah hukum Polresta Yogyakarta sudah dilakukan oleh petugas walaupun belum maksimal.

Kepolisian Polresta Yogyakarta dan Dinas Perhubungan mempunyai porsi-porsinya masingmasing ketika sedang melakukan operasi tilang gabungan. Dinas Perhubungan akan memberikan tilang kepada kendaraan angkutan penumpang dan kendaraan angkutan barang.

\section{Gambar 2. Surat tilang dari Dinas Perhubungan}

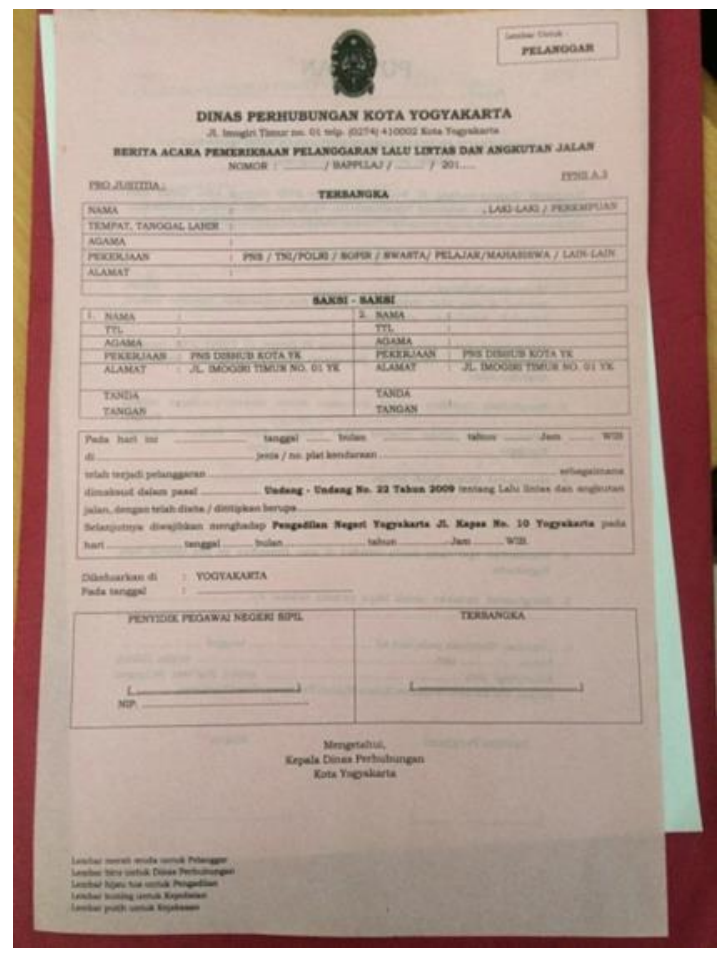

Sumber : Diolah dari data di Polresta Yogyakarta

Kendaraan angkutan penumpang dan kendaraan angkutan barang yang melanggar lalu lintas akan dikenai surat tilang oleh Dinas Perhubungan, sebagaimana dijelaskan pada gambar 2 . Mekanisme nya sama seperti petugas kepolisian, yaitu Dinas Perhubungan akan memberikan surat tilang kepada pelanggar untuk nantinya dibayarkan ke BRI. Setelah itu barang-barang sitaan akan diberikan pada saat proses persidangan selesai. Namun apabila Supir Truk yang tidak memiliki SIM ataupun STNK akan dilimpahkan kepada petugas Kepolisian dikarenakan pihak kepolisian yang memiliki kewenangan untuk mengurus kelengkapan berkendara.

Dinas Perhubungan sendiri untuk terkait E-Tilang masih belum menerapkan, karena hingga saat ini Dinas Perhubungan masih menggunakan sistem secara manual, sehingga Dinas Perhubungan terkait E-Tilang tidak mempunyai hambatan-hambatan seperti halnya petugas Kepolisian. 


\section{Gambar 3. Surat tilang elektronik}

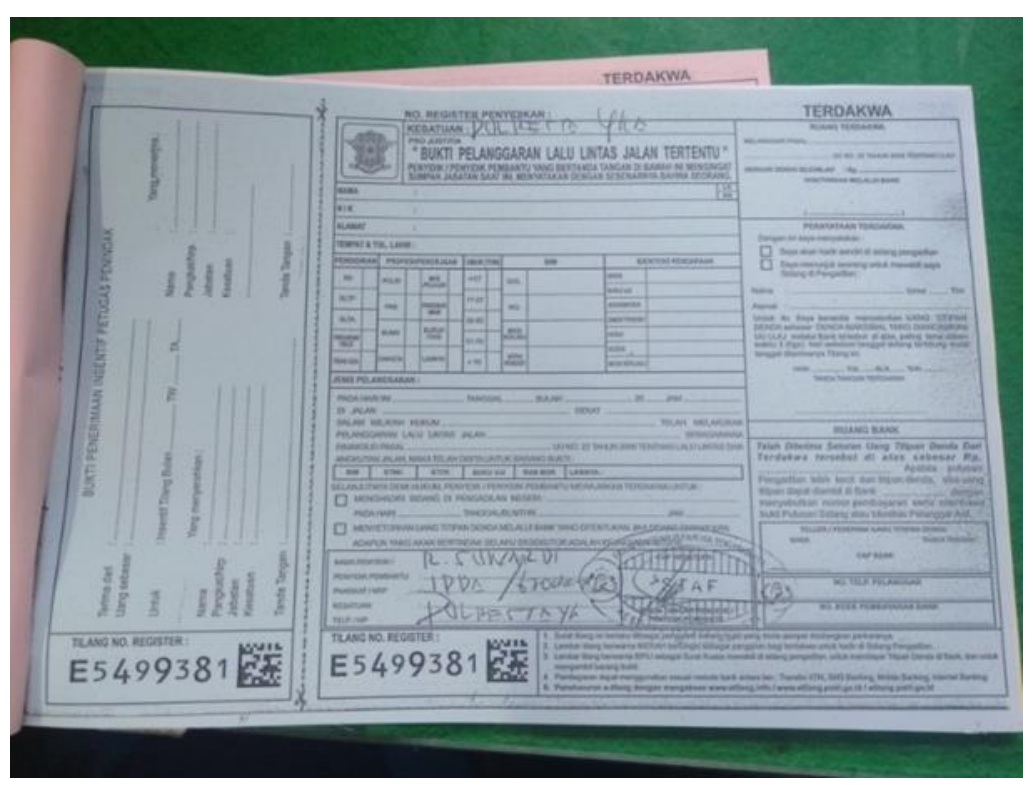

Sumber : Diolah dari data di Polresta Yogyakarta

Apabila pelanggar memilih surat tilang berwarna biru sebagaimana dijelaskan pada gambar 3, berarti pelanggar memilih di tilang dengan menggunakan sistem baru yaitu E-Tilang. Terkait dengan E-Tilang sendiri yang berada di wilayah hukum Polresta Yogyakarta sudah mulai beroperasi pada bulan Februari 2017.

Pelaksanaan E-Tilang di wilayah hukum Polresta Yogyakarta tentunya memiliki sistemnya tersendiri. Mekanisme Tilang itu sendiri alurnya adalah ketika polisi telah menilang secara manual (menulis di blangko tilang), selanjutnya kemudian Polisi memasukan data kembali ke aplikasi ETilang yang terdapat di dalam handphone milik petugas kepolisian yang saat itu sedang berjaga dan sudah terintegrasi dengan server E-Tilang Korlantas Polri (Mabes Polri) sesuai dengan data pelanggar termasuk dengan nomor tilangnya, sebagaimana dijelaskan pada bagan 1 . Maka sistem informasi setiap pelanggaran oleh para pengendara di jalan raya harus dapat menjadi dasar penindakan pelanggaran dalam tahapan selanjutnya, artinya informasi pelanggaran yang pernah dilakukan setiap orang harus selalu teridentifikasi oleh setiap anggota polisi yang melakukan tilang. ${ }^{6}$

\section{Bagan 2. Mekanisme Informasi E-Tilang}

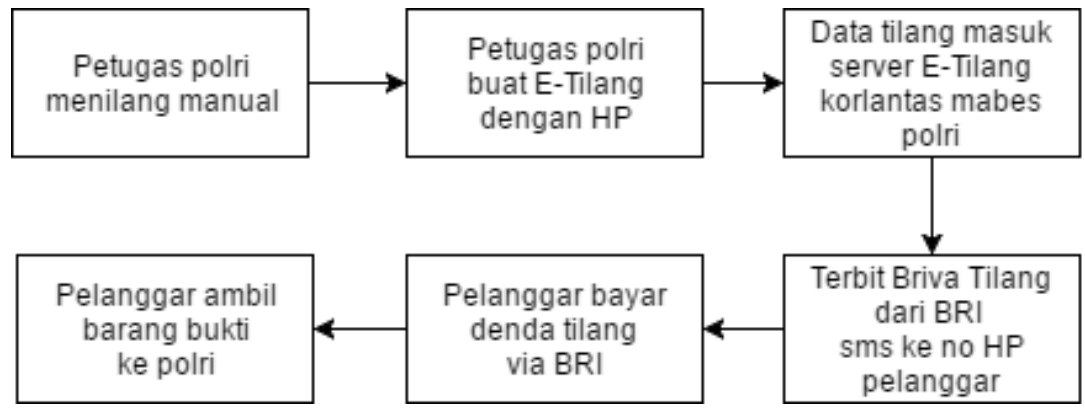

Sumber: Polresta Yogyakarta

6 Rahardian IB. Dian AK, Program Aplikasi Berbasis Wap Untuk Peningkatan Akuntabilitas Sistem Tilang Pelanggaran Tata Tertib Lalu Lintas Di Wilayah Polres Majalengka, Jurnal Online ICT-STMIK IKMI, 2011, Volume 1 Nomor 1, hlm. 43. 
Terkait dengan sistem informasi, E-Tilang mempunyai mekanisme alur informasinya sendiri, sebagaimana dijelaskan pada bagan 2. Bagan tersebut menjelaskan bahwa data tilang yang masuk ke server korlantas, nantinya akan terhubung secara otomatis ke BRI.

Proses selanjutnya yaitu ketika berhasil di simpan akan muncul nomor BRIVA dari BRI kemudian server E-Tilang secara otomatis akan mengirim pemberitahuan jumlah uang titipan denda yang bisa dibayarkan di bank seperti pada gambar 4 beserta pasal berapa yang dilanggar oleh si pelanggar tersebut. Setelah membayar uang titipan denda Tilang (belum vonis) maka barang bukti tilang bisa di tukar dengan uang titipan denda tersebut.

Pelanggar yang sudah menyelesaikan pembayaran, dapat kembali lagi ke Pos Polisi untuk mengambil barang yang telah disita dengan menunjukan bukti pembayaran denda kepada pihak kepolisian lalu lintas. Pelanggar tidak perlu ke Pengadilan untuk melakukan proses persidangan. Data pelanggar kemudian dikirim ke pengadilan untuk menerima ketetapan hakim, setelah itu Jaksa mengeksekusi amar/putusan tilang, selanjutnya pelanggar akan menerima notifikasi berisi amar/putusan tilang dan sisa dana tilang apabila terdapat sisa dari pembayaran denda tilang.

Akan tetapi E-Tilang mempunyai jangka waktu kadaluarsa pembayaran, yaitu hanya berlaku tiga sampai lima hari. Apabila telah melampaui batas yang ditentukan yaitu tiga sampai lima hari dan sudah kadaluarsa, maka pelanggar tadi harus menjalani proses sidang, dan barang-barang sitaan milik pelanggar dari pihak kepolisian akan diserahkan kepada Kejaksaan. Kepolisian Polresta Yogyakarta saat menjalankan operasi tilang gabungan, akan melakukan kerja sama dengan Dinas Perhubungan Yogyakarta.

\section{Gambar 4. Server Polantas Yogyakarta}

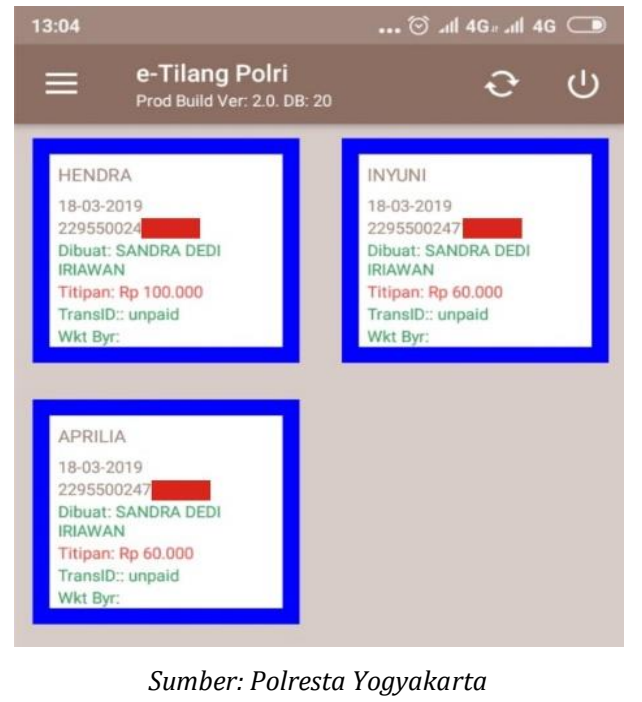

Kelebihan dari sistem E-Tilang sendiri adalah memudahkan pelanggar yang tidak berdomisili di wilayah hukum Polresta Yogyakarta. Apabila ada seseorang yang berkunjung ke Yogyakarta dari luar kota, dan melakukan pelanggaran lalu lintas, maka pelanggar tersebut dapat memilih dengan sistem E-Tilang, karena dengan menggunakan E-Tilang, pelanggar dapat membayar uang titipan denda tanpa harus menghadiri persidangan.

E-Tilang sejauh ini terkait dengan sistem pelaksanaanya dapat terbilang lancar dan tidak memiliki hambatan yang banyak, hambatan yang terjadi pun biasanya diakibatkan dari errornya server korlantas yang terhubung dengan handphone milik petugas kepolisian, apabila tidak terjadi koneksi yang error, maka tidak ada hambatan.

Seseorang yang melanggar peraturan atau tata tertib yang sudah dibuat dan ditetapkan oleh penegak hukum, maka akan dikenakan sanksi kepada si pelanggar tersebut. Sanksi yang diberikan bertujuan untuk memberikan efek jera, sebagai hukuman kepada si pelanggar atas apa yang telah ia lakukan, karena telah melanggar peraturan atau tata tertib. Sanksi yang diberikan diharapkan mampu memberikan kesadaran serta efek jera, agar kedepannya si pelanggar tersebut tidak melakukan atau mengulangi tindakan nya kembali. Secara konvensional dapat diadakan 
pembedaan antara sanksi positif yang merupakan imbalan, dengan sanksi negatif yang berupa hukuman. ${ }^{7}$ Secara umum bentuk-bentuk hukuman dalam hukum pidana adalah, misalnya denda dan hukuman badan. ${ }^{8}$

Berdasarkan dari hasil wawancara yang telah dilakukan oleh peneliti dengan Bapak IPTU Suwardi. Selaku KAUR BIN OPS Lantas di Polresta Yogyakarta pada tanggal 31 Mei 2019, menurut narasumber terkait dengan pelimpahan tilang dari kepolisian ke pengadilan menggunakan ketentuan KUHAP seperti aspek tipiring. Berkas secara fisik dilimpahkan ke pengadilan sesuai ketentuan bila sudah membayar uang titipan denda dilampirkan bukti bayar atau struk atm dari bank BRI, untuk eksekusi denda oleh kejaksaan setelah putusan sidang.

Undang-undang Nomor 22 tahun 2009 tentang Lalu Lintas dan Angkutan Jalan, di dalamnya memuat berbagai sanksi bagi pelanggar lalu lintas, hal ini dilakukan sebagai upaya untuk mengurangi dari tindakan pelanggaran lalu lintas itu sendiri. Dalam Hukum Pidana terdapat dua jenis perbuatan, yaitu kejahatan dan pelanggaran. Sanksi pelanggaran lalu lintas ini oleh karena itu termasuk kedalam ruang lingkup hukum pidana.

Sanksi yang diberikan kepada Pelanggar Lalu Lintas atau pada umunya disebut dengan istilah "tilang". Apabila Polisi Lalu Lintas secara langsung melihat kejadian ketika pengguna jalan melanggar lalu lintas. Maka Polisi berhak untuk menindak pelaku pelanggar lalu lintas, dengan ketentuan yang sesuai dengan hukum yang berlaku.

Penerapan sanksi E-Tilang di wilayah hukum Polresta Yogyakarta itu sendiri adalah ketika seseorang yang tertangkap tangan melakukan pelanggaran lalu lintas, maka sanksinya adalah diberikan Tilang dari petugas kepolisian. Seperti penjelasan diatas nantinya si pelanggar akan diberikan pilihan untuk memilih tilang manual atau tilang elektronik.

Pelanggar yang sudah memilih salah satu diantara tilang manual atau tilang elektronik, nantinya akan di kenai denda pelanggaran. Denda pelanggaran itu sendiri bermacam-macam, tergantung pelanggaran apa yang di langgar oleh si pengguna jalan. Adapun macam-macam pelanggaran lalu lintas yang dilakukan oleh pengendara roda dua adalah sebagai berikut.

Tabel 1. Jenis Pelanggaran Lalu Lintas Roda Dua Tahun 2017 dan 2018

\begin{tabular}{|c|c|c|c|c|c|c|c|c|c|c|c|}
\hline \multirow[b]{2}{*}{$\mathrm{NO}$} & \multirow[b]{2}{*}{ KESATUAN } & \multirow[b]{2}{*}{$\begin{array}{c}\text { JUMLAH } \\
\text { PELANGGAR }\end{array}$} & \multicolumn{9}{|c|}{ JENISPELANGGARAN YANGDLLAKUKAN } \\
\hline & & & HELLI & $\begin{array}{c}\text { KELENGKAPAN } \\
\text { KENDARAAN }\end{array}$ & SURATSIRAT & $\begin{array}{c}\text { BONCENGLEBIH } \\
\text { DARI10RANG }\end{array}$ & $\begin{array}{l}\text { MARKA } \\
\text { RAMBU }\end{array}$ & $\begin{array}{c}\text { MELAWAN } \\
\text { ARLSS }\end{array}$ & $\begin{array}{c}\text { ANAK } \\
\text { DIBAWAH } \\
\text { UNUR }\end{array}$ & $\begin{array}{c}\text { GLNAKAN } \\
\text { HP }\end{array}$ & KECEPATAN \\
\hline 1 & 2017 & 25902 & 1680 & 551 & 9911 & 28 & 11545 & 1489 & 541 & 157 & 0 \\
\hline 2 & 2018 & 23763 & 1606 & 461 & 4362 & 31 & 12514 & 4104 & 548 & 137 & 0 \\
\hline
\end{tabular}

Sumber: Polresta Yogyakarta

Berdasarkan tabel tersebut di atas, dapat disimpulkan bahwa tingkat pelanggaran lalu lintas terbesar dilakukan oleh pengendara roda dua, dan untuk pelanggaran yang sering dilakukan adalah melanggar marka rambu, selanjutnya pelanggaran yang sering dilakukan adalah tidak mempunyai surat kelengkapan berkendara seperti SIM dan STNK. Pelanggaran yang terjadi pada saat tahun 2017 sejak pertama E-Tilang berlaku di Yogyakarta, dan selanjutnya berlanjut di tahun 2018 mengalami jumlah penurunan pelanggaran lalu lintas untuk kendaraan roda dua.

\footnotetext{
7 Soerjono Soekanto, Efektivikasi Hukum dan Penerapan Sanksi, Bandung, Remadja Karya, 1985. hlm. 82.
}

8 Ibid, hlm. 83. 
Tabel 2. Jenis Pelanggaran Lalu Lintas Roda Empat Tahun 2017 dan 2018

\begin{tabular}{|c|c|c|c|c|c|c|c|c|c|c|c|}
\hline \multirow[b]{2}{*}{ N0 } & \multirow[b]{2}{*}{ TAHUN } & \multirow[b]{2}{*}{$\begin{array}{c}\text { JUMLAH } \\
\text { PELANGGARAN }\end{array}$} & \multicolumn{9}{|c|}{ JENIS PELANGGARAN YANG DILAKUKAN } \\
\hline & & & KECEPATAN & MUATAN & $\begin{array}{c}\text { KELENGKAPAN } \\
\text { KENDARAAN }\end{array}$ & $\begin{array}{l}\text { SURAT } \\
\text { SURAT }\end{array}$ & $\begin{array}{c}\text { SAFETY } \\
\text { BELT }\end{array}$ & $\begin{array}{l}\text { MARKA } \\
\text { RAMBU }\end{array}$ & $\begin{array}{c}\text { MELAWAN } \\
\text { ARUS }\end{array}$ & $\begin{array}{c}\text { ANAK } \\
\text { DIBAWAH } \\
\text { UMUR }\end{array}$ & $\begin{array}{c}\text { GUNAKAN } \\
\text { HP }\end{array}$ \\
\hline 1 & 2017 & 1729 & 0 & 35 & 0 & 262 & 153 & 1136 & 22 & 0 & 121 \\
\hline 2 & 2018 & 1702 & 0 & 44 & 0 & 57 & 200 & 1283 & 0 & 0 & 118 \\
\hline
\end{tabular}

Sumber: Polresta Yogyakarta

Berdasarkan tabel tersebut diatas dapat disimpulkan bahwa jenis pelanggaran yang sering dilakukan oleh pengendara roda empat adalah melanggar marka rambu. E-Tilang yang berlaku sejak Februari 2017 memberikan dampak juga terhadap pengendara roda empat, di tahun 2018 yang mengalami penurunan tingkat pelanggaran lalu lintas.

Tabel 3. Pelanggaran Lalu Lintas Tahun 2017 dan 2018

\begin{tabular}{ccccc}
\hline NO & TAHUN & E-TILANG & MANUAL & $\begin{array}{c}\text { JUMLAH } \\
\text { TILANG }\end{array}$ \\
\hline 1 & 2017 & 7.200 & 13.045 & 20.245 \\
2 & 2018 & 22.464 & 7.445 & 29.909 \\
\hline \multicolumn{4}{r}{ Sumber: Polresta Yogyakarta }
\end{tabular}

Berdasarkan tabel tersebut diatas dapat disimpulkan bahwa sejak berlakunya E-Tilang pada Februari 2017, selanjutnya ditahun berikutnya pada tahun 2018 mengalami peningkatan tingkat pelanggaran lalu lintas.

Denda yang di terapkan pada kasus pemberian sanksi Elektronik Tilang panduan dendanya diperoleh dari pengadilan', pada kasus tersebut namun apabila hakim di pengadilan sudah memutuskan, barulah kasus tersebut bisa dikatakan selesai. Untuk vonis putusan, Pengadilan akan mengumumkan via website resmi pengadilan tentang besaran dendanya, kemudian dari Kejaksaan hanya membuat surat ke Polisi. Adapun jenis pelanggaran berikut dengan dendanya adalah sebagai berikut.

Tabel 4. Jenis Pelanggaran Lalu Lintas

\begin{tabular}{|c|c|c|c|c|}
\hline \multirow{2}{*}{ NO } & \multirow{2}{*}{ PASAL } & \multirow{2}{*}{ KESALAHAN } & \multicolumn{2}{|c|}{ DENDA } \\
\hline & & & $\mathbf{R} 2$ & R4 \\
\hline \multirow[t]{2}{*}{1} & $275(1)$ & Mengganggu kinerja rambu / APILL & Rp $125.000,-$ & Rp 145.000,- \\
\hline & $275(2)$ & Merusak rambu lalu lintas / APILL & Rp 125.000,- & Rp 145.000,- \\
\hline 2 & 276 & Angkutan umum tidak singgah terminal & & Rp 250.000,- \\
\hline 3 & 277 & Modifikasi kendaraan menyalahi aturan & Rp 125.000,- & Rp 145.000,- \\
\hline 4 & 278 & Perlengkapan R4 tidak dibawa / tidak lengkap & & Rp 80.000,- \\
\hline 5 & 279 & Perlengkapan yang menonjol & Rp 60.000,- & Rp 80.000,- \\
\hline 6 & 280 & Tanpa plat nomor & Rp 60.000,- & Rp 80.000,- \\
\hline 7 & 281 & Tidak punya SIM & Rp 125.000,- & Rp 145.000,- \\
\hline 8 & 282 & Tidak mematuhi aturan polisi & Rp 40.000,- & Rp 60.000,- \\
\hline 9 & 283 & Mabuk & Rp 60.000,- & Rp 80.000,- \\
\hline 10 & 284 & Pejalan kaki & Rp 60.000,- & Rp 80.000,- \\
\hline
\end{tabular}

\footnotetext{
${ }_{9}^{9}$ Iptu Suwardi. KAUR BIN OPS Lantas dalam wawancara di Polresta Yogyakarta,14 Maret 2019.
} 
Rp 40.000,-

Rp 60.000,-

Rp 60.000,-

Rp 60.000,-

Rp 60.000,-

Rp 40.000,-

Rp 40.000,-

Rp 60.000,-

Rp 40.000,-

Rp 60.000,-

Rp 40.000,-

Rp 60.000,-

Rp 40.000,-

Rp 40.000,-

Rp 40.000,-

Rp 40.000,-

Rp 40.000,-

Rp 30.000,-

Rp 40.000,-

Rp 40.000,-

Rp 40.000,-

Rp 2.000.000,-

Rp 100.000,-

Rp 120.000,-

Rp 60.000,-

Rp 80.000,-

Rp 60.000,-

Rp 80.000,-

Rp 80.000,-

Rp 80.000,-

Rp 145.000,-

$40 \quad 302 \quad$ Angkutan tidak berhenti di tempat yang ditentukan atau jalan menyalahi trayek

$41303 \quad$ Mobil barang angkut orang

Sumber: Polresta Yogyakarta

\section{Simpulan dan Saran}

\section{Simpulan}

Berdasarkan apa yang telah diuraiankan dalam bab pembahasan dan analisis data, maka peneliti dapat menarik kesimpulan diantaranya:

Proses penegakan hukum E-Tilang dalam menyelesaikan tindak pidana pelanggaran lalu lintas telah berpedoman pada Undang-Undang Nomor 29 Tahun 2009 tentang Lalu Lintas dan Angkutan Jalan, alurnya adalah ketika polisi telah menilang secara manual (menulis di blangko tilang), selanjutnya kemudian Polisi memasukan data kembali ke aplikasi E-Tilang yang terdapat di dalam handphone milik petugas kepolisian yang saat itu sedang berjaga dan sudah terintegrasi dengan server E-Tilang Korlantas Polri (Mabes Polri) sesuai dengan data pelanggar termasuk dengan nomor tilangnya. 
Proses selanjutnya yaitu ketika berhasil di simpan akan muncul nomor BRIVA dari BRI kemudian server E-Tilang secara otomatis akan mengirim pemberitahuan jumlah uang titipan denda yang bisa dibayarkan di bank beserta pasal berapa yang dilanggar oleh si pelanggar tersebut. Setelah membayar uang titipan denda Tilang (belum vonis) maka barang bukti tilang bisa di tukar dengan uang titipan denda tersebut.

Pelanggar yang sudah menyelesaikan pembayaran, dapat kembali lagi ke Pos Polisi untuk mengambil barang yang telah disita dengan menunjukan bukti pembayaran denda kepada pihak kepolisian lalu lintas. Pelanggar tidak perlu ke Pengadilan untuk melakukan proses persidangan. Data pelanggar kemudian dikirim ke pengadilan untuk menerima ketetapan hakim, setelah itu Jaksa mengeksekusi amar/putusan tilang, selanjutnya pelanggar akan menerima notifikasi berisi amar/putusan tilang dan sisa dana tilang apabila terdapat sisa dari pembayaran denda tilang.

Penerapan sanksi yang akan diberikan kepada pelanggar Tilang Elektronik yang dimana apabila saat pelanggar lalu lintas tertangkap tangan oleh petugas polisi secara langsung, selanjutnya pelanggar akan diberikan sanksi denda sesuai dengan pelanggaran yang dilakukan, yang dimana sanksi denda tersebut dapat dibayarkan melalui bank Bank Rakyat Indonesia (BRI).

\section{Saran} berikut :

Adapun saran yang peneliti berikan berhubungan dengan penelitian ini yaitu sebagai

a. Diharapkan kepada pihak kepolisian untuk lebih menggalakan sosialisasi kepada masyarakat kembali, supaya masyarakat lebih paham dengan penggunaan sistem ETilang agar kedepannya masyarakat lebih mengetahui dan paham terkait E-Tilang itu sendiri, dan di harapkan kedepannya E-Tilang dapat berkembang lebih baik untuk kelengkapan sistemnya seperti penambahan CCTV, Speaker dan lain sebaginya, sehingga E-Tilang tidak hanya disebut Elektronik karena proses pembayarannya yang melalui sistem Elektronik.

\section{DAFTAR PUSTAKA}

\section{Buku}

Soerjono Soekanto. 2010. Pengantar Penelitian Hukum. Jakarta. UI-Press.

Mukti fajarND dan Yulianto Achmad. 2017. Dualisme Penelitian Hukum Normatif dan Empiris. Yogyakarta Pustaka Pelajar.

Soerjono Soekanto. 1985. Efektivikasi Hukum dan Penerapan Sanksi. Bandung. Remadja Karya.

\section{Perundang-Undangan}

Undang-Undang Nomor 22 Tahun 20019 Tentang Lalu Lintas dan Angkutan Jalan

\section{Jurnal}

Abdul Azis, Dias Ayu Budi Utami dan Albertus Novian BT, 2018, Prototype Data Warehouse Aplikasi eMTilang, Jurnal Sistem Informasi \& Manajemen Basis Data (SIMADA), Vol. 1 No. 2

Rahardian IB. Dian AK. 2011. "Program Aplikasi Berbasis Wap Untuk Peningkatan Akuntabilitas Sistem Tilang Pelanggaran Tata Tertib Lalu Lintas Di Wilayah Polres Majalengka". Jurnal Online ICT-STMIK IKMI. Volume 1. Nomor 1.

Setiyanto. 2017. "Efektivitas Penerapan Sanksi Denda E-Tilang Bagi Pelanggar Lalu Lintas Berdasarkan Undang-Undang Nomor 22 Tahun 2009 Tentang Lalu Lintas Dan Angkutan Jalan (Studi Di Polres Rembang)". Jurnal Hukum Khaira Ummah. Volume. 12. Nomor 4. 


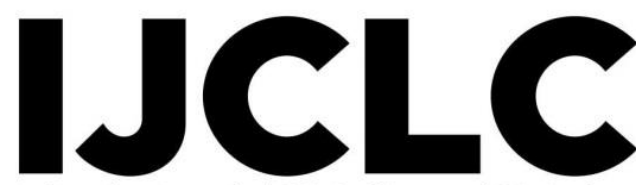

Indonesian Journal of Criminal Law and Criminology
Pusat Kajian Hukum Pidana dan Kriminologi

Fakultas Hukum Universitas Muhammadiyah Yogyakarta

Jalan Brawijaya, Kasihan, Bantul, Yogyakarta 55183

Telp. (0274) 387656 Ext. 472

Fax. 0274-387656

E-mail : cclcs@umy.ac.id

\section{Internet}

http://indrayanti_prastica-fisip15.web.unair.ac.id.Diakses pada tanggal 8 Mei 2019, pukul 23.12 WIB. 